\title{
COMPARISON OF PLEXUS BRACHIAL BLOCKADE EFFECT BY SUPRACLAVICULAR AND AXILLARY APPROACH - OUR EXPERIENCE
}

\author{
Ismet Suljević ${ }^{1}$, Omer Suljević ${ }^{4}$, Maida Turan ${ }^{3}$, Amela Grbo ${ }^{1}$ and Ismana Surković ${ }^{2}$ \\ ${ }^{1}$ University Clinical center Sarajevo, Clinic for anesthesiology and resuscitation, Bosnia and Herzegovina; \\ ${ }^{2}$ University Clinical center Sarajevo, Department for Endocrinology, diabetes and metabolic diseases, \\ Bosnia and Herzegovina; ${ }^{3}$ Achibadem Office in Sarajevo, Bosnia and Herzegovina; \\ ${ }^{4}$ Medical Faculty of Univesity in Sarajevo, Bosnia i Herzegovina
}

\begin{abstract}
SUMMARY - Introduction. Brachialis plexus block is a frequently used method of regional anesthesia that can be performed in several ways and locations. It has been successfully performed to provide good anesthesia and analgesia lasting several hours for operative procedures on hands. It can be performed by paresthesia technique or by ultrasound that has almost pushed out the old conventional technique since it allows the visualization of the blockade performance. Target. In the paper we use our sample to try to determine which of the two locations of the blockageis more favorable for the patient, and which one gives a higher percentage of success or a better sensory blockade. Method. This is a retrospective study and includes 40 patients of both sexes that were operated on at the Clinic for Traumatology and the Clinic for Plastic Surgery of the University Clinical Center in Sarajevo in the period from 30 August 1993 to 30 August 1994. Patients were divided into two groups. Group I were patients who had an axillary approach to plexus brachialis (n-21) ASA I-II. Group II were patients who had supraclavicular access to plexus brachialis (n-19) ASA I-II. All patients received $0.5 \mathrm{ml} / \mathrm{kg}$ Bupivacaine $0.5 \%$. In the study, we analyzed sex, age, duration of blockade and complications. Analgesia and motor block were evaluated 20 minutes after the local anesthetic injection. The complete block is defined as analgesia in all dermatomes (C5-Th1) 20 minutes after injection. The results. Group I had 20 male and 1 female patients while group II had 17 male and 2 female patients. The supraclavicular block enabled complete blockade in 18 patients (95.23\%), and the axillary approach had a successful blockade in 17 patients (80.95\%). In both groups the corresponding motor block was similar. The start of the engine block was similar in both groups. There were no significant complications in either group. Conclusion. Regarding clinical efficacy, both brachial plexus blocking approaches provided a good motor block, anesthesia and analgesia for the forearm or hand surgery. Supraclavicular approach proved to be more favorable.
\end{abstract}

Keywords: axillary block, regional anesthesia, bupivacaine.

\section{Introduction}

Brachial plexus block is usually used as anesthesia and analgesia for operation on upper extremities. Many other authors informed us that over $90 \%$ of an-

Correspondence to: Ismet Suljevic, $\mathrm{MD}, \mathrm{MSc}, \mathrm{PhD}$, University Clinical center Sarajevo, Clinic for anesthesiology and resuscitation, Bosnia and Herzegovina, Bolnička 25, Sarajevo

E-mail: ismetsul@bih.net.ba esthesiologists are using axillary approach, because of the advantages, simplicity, and safety. Many anesthesiologists are still using axillary block without the use of neurostimulator or ultrasound, by using the technique of getting the paresthesia feeling in the patient's arm. This technique is used by injecting anesthetic for axillary block in one point, while other anesthesiologists are using techniques of multiple injections in two or three points (1). An increasing number of anesthesi- 
ologists are using ultrasound in regional anesthesia. Blockage of plexus brachialis can be done by other approaches - from front or back interscalene, supraclavicular, infraclavicular, subacromial. Different local anesthetics can be used for anesthesia, as single or as a bundle of anesthetics. Anesthetics of amido group, such as: lidocaine, bupivacaine, articaine, etidocaine, mepivacaine are usually used. The first blockage of upper extremity nerve was done in 1884 by Halsted (2). Hirschel and KulenKampff were the first to accomplish a percutaneous block of brachial plexus and they described it in 1891. Supraclavicular block of brachial plexus is done by a procedure that was published by Brow et al. (3). In our study we will try to show the effect of blockage in two plexus brachialis approaches. New studies of different approaches and techniques, based on a sufficient number of patterns, should compare the effect, complications and side effects.

\section{Method}

Study was retrospective and it included 40 patients of both genders, aged from 22-66, operated at the Clinic for traumatology and Clinic for plastic surgery on University Clinical center in Sarajevo in the period from 30 August 1993 until 30 August 1994. Patients were divided in two groups. Data used comes from the author's work evidence documentation. All procedures were done by the same anesthesiologist. Group I are patients that had had axillar approach to plexus brachialis (n-21) ASA I-II score. Group II are patients that had had supraclavicular approach to plexus brachialis (n-19) ASA I-II score. All patients received 0.5 $\mathrm{ml} / \mathrm{kg}$ Bupivacaine $0.5 \%$. Baby system was used for the puncture, with flexible wings with a tube for connection of $20 \mathrm{ml}$ syringe. The chosen position of the needle was the one that was considered the most convenient while getting the answer from the patient about the distribution of paresthesia through hand and forearm. Local anesthetic Bupivacaine 0.5\% (Pliva, $\mathrm{Za}$ greb, Croatia) was used for all blocks, it was applied in duration of $30 \mathrm{sec}$ while aspirating carefully. Assistant injected the anesthetic with the anesthesiologist's approval. In the study we have analyzed gender, age and complications. Analgesia and motor block was estimated 20 minutes after the injection of local anesthetic. Analgesia was controlled by a soft touch on the skin surface by a sterile needle on many locations on the forearms. Patients with axillar approach had Esmarch bandage placed under the location of puncture that lasted for 5 minutes. Patients whose blocks were not adequate received balanced general anesthesia. Complete block was defined as analgesia in all dermatomes (C5-Th1) 20 minutes after injection. Criteria for inclusion in the study were patients with trauma or indication for operation on hand and forearm. Criteria of exclusion involved refusing the operation with this type of anesthesia by the patient, allergies to local anesthetics, lung, heart, liver or kidney disease and pregnancy. To perform the supraclavicular block, patient was lying on the back with head turned towards the other side. Point of puncture was marked in the lateral border of sternocleidomastoid muscle where it connects with clavicle, and needle was pointed towards back and down, after the previous palpation of subclavian artery. Needle has progressed until the paresthesia response was received. If during the puncture there was no reaction in the hand or wrist, the direction of the needle was carefully corrected until a proper reaction was received in the hand of wrist. Axillary block was done in a lying position with the arm flexed in the elbow and abduction of the forearm. Needle puncture was done by palpating art. axillaris, until getting the paresthesia reaction or motor response on hand and fingers. Sensory block was controlled with a skin test with gauze containing cold alcohol. Motor block was estimated by commanding the patients to lift their forearm by flexing it and to move their fingers. A degree of motor block was marked with grade 5 if there was no reaction, grade 3 if the reactions were minimal, and grade 1 if motor functions were preserved.

Complete quality of block in intraoperative time was considered to be a bad block if in the end there was a need for general anesthesia, and if the operation went without patient's discomfort or need for conversion of anesthesia, it was considered a good block.

Some of the complications have been reported, such as puncture of blood vessels and Horner syndrome.

We analyzed the results statistically. The values are expressed as the mean value \pm SD. Statistical analysis was carried out using Student's t-test. The value of $\mathrm{P}$ $<0.05$ was considered statistically significant. 


\section{Results}

In Group I, there were 20 male patients and $1 \mathrm{fe}-$ male patient. In Group II there were 17 male patients and 2 female patients. The average age of patients in Group I was 37.95 y. in Group II 37.10 y. so there was no significant age difference ( $p>0.05$ ) (Table 1). The supraclavicular block provided complete blockage in 18 patients $(95.23 \%)$, and the axillary approach had a successful blocking in 17 patients (80.95\%). In $4 \mathrm{pa}^{-}$ tients in Group I, general anesthesia was applied due to poor sensory and motor block. There was no significant difference in the quality of the motor block between the groups ( $>$ > 0.05) (Table 2). The start of the motor block was similar in both groups. There were no

Table 1. t-Test: Two-Sample Assuming Unequal Variances

\begin{tabular}{|l|l|l|}
\hline & Variable 1 & Variable 2 \\
\hline Mean & 37.10526316 & 37.95238095 \\
\hline Variance & 159.877193 & 123.947619 \\
\hline Observations & 19 & 21 \\
\hline $\begin{array}{l}\text { Hypothesized Mean } \\
\text { Difference }\end{array}$ & 0 & \\
\hline $\mathrm{df}$ & 36 & \\
\hline $\mathrm{t}$ Stat & -0.223882406 & \\
\hline $\mathrm{P}(\mathrm{T}<=\mathrm{t})$ one-tail & 0.412057262 & \\
\hline $\mathrm{t}$ Critical one-tail & 1.688297714 & \\
\hline $\mathrm{P}(\mathrm{T}<=\mathrm{t})$ two-tail & 0.824114523 & \\
\hline $\mathrm{t}$ Critical two-tail & 2.028094001 & \\
\hline
\end{tabular}

Table 2. t-Test: Two-Sample Assuming Unequal Variances

\begin{tabular}{|l|l|l|}
\hline & Variable 1 & Variable 2 \\
\hline Mean & 4.684211 & 4.047619 \\
\hline Variance & 1.005848 & 2.647619 \\
\hline Observations & 19 & 21 \\
\hline $\begin{array}{l}\text { Hypothesized Mean } \\
\text { Difference }\end{array}$ & 0 & \\
\hline $\mathrm{df}$ & 34 & \\
\hline $\mathrm{t}$ Stat & 1.504577 & \\
\hline $\mathrm{P}(\mathrm{T}<=\mathrm{t})$ one-tail & 0.070833 & \\
\hline $\mathrm{t}$ Critical one-tail & 1.690924 & \\
\hline $\mathrm{P}(\mathrm{T}<=\mathrm{t})$ two-tail & 0.141667 & \\
\hline $\mathrm{t}$ Critical two-tail & 2.032245 & \\
\hline
\end{tabular}

significant complications in either group. During the procedure of placing the needle for the axillary block, the axillary artery was perforated 3 times, while in the supraclavicular approach 2 times the blood was aspirated from art. subclavia.

\section{Discussion}

A brachial plexus block can be performed with several approaches. The choice of the preferred approach is determined by the innervation of the surgical site, the risk of complications associated with regional anesthesia, and with tendency as well as experience of the anesthesiologist.

In this study, supraclavicular and axillary access to the brachial plexus using paresthesia did not show significant clinical differences, except for a milder Horner syndrome in one patient with a supraclavicular approach.

Supraclavicular access to the brachial plexus can provide excellent anesthesia for the upper extremity surgery. Compared to the axillary block, the supraclavicular approach to the brachial plexus has a distinct advantage, especially a faster start of the block with one injection with less local anesthetics (4). However, many anesthesiologist do not want to perform this technique because of the fear of causing pneumothorax. By using ultrasound techniques, serious complications of a supraclavicular approach such as pneumothorax can be avoided. Perlas et. al. reported that the ultrasound-guided supraclavicular block was associated with a high success rate and a low rate of complications without pneumothorax in a series of 510 consecutive patients. The described incidence of pneumothorax in the supraclavicular block is $0.5 \%$ to $6.1 \%$. It can be reduced by the experience of an anesthesiologist or using shorter needles (5).

In our study, the supraclavicular approach showed better results in terms of complete sensory and motor blockade. In 20 minutes, a total anesthesia was achieved in $95.23 \%(\mathrm{n}=19)$ of patients in Group II compared to $80.95 \%(\mathrm{n}=21)$ in Group I.

In the supraclavicular approach, Franco et al. in their study reported $97.2 \%$ success rate of perivascular techniques in 1001 patients. Possible reasons for a lower success rate in both blocks include the possible inexperience of anesthesiologists, the smaller volume of the 
used local anesthetics, and use of different local anesthetics in insufficient quantity or concentration (6).

In our study, the blood vessel puncture was present in both groups. However, after compression of the puncture site there was no hematoma. The absence of arterial puncture can be achieved by a slow and careful injection technique with repeated aspiration and the use of atraumatic needles.

The combined supraclavicular block and cervical plexus superficial block done under ultrasound control can be a successful competitor in the interscalen approach to plexus brachialis to avoid possible complications associated with the plexus block, and more research is needed in the near future (7).

The blockage of the brachial plexus provides excellent anesthesia for many procedures at the upper extremities and provides good vasodilation of the blood vessels of the arm, which can be a favorable moment in the AV fistula surgery in preparation for hemodialysis (8).

For the prolongation of the duration of the brachial plexus block, some authors recommend the addition of dexmedetomidine, which is better in prolonging the duration of the supraclavicular block, and the improvement of postoperative analgesia from fentanyl and bupivacaine without significant adverse effects in patients undergoing surgery of the upper extremities (9).

An axillary approach to the brachial plexus provides greater safety to the anesthesiologist in reducing possible complications, especially if using ultrasound techniques. In this sense, adding the block of $\mathrm{n}$. Axilaris and n. Coracobrahialis enables the completeness of the axillary block of the brachial plexus $(10,11,12,13)$.

In the axillary approach of the plexus brachialis blocks, certain variations can also be made in terms of moving the puncture site towards the body in the axilla with the ultrasound guided supraxillary block where the nerves are closer to each other, which may result in a better block after the application of the anesthetics $(14,15)$.

Without a doubt, the two described approaches and methods of blocking plexus brachialis, present conventional methods that are not yet to be rejected, especially since we still have potential problems in securing material and technical means and the inability to use US machines. That is why research in this field should continue to achieve the best possible results.

\section{Conclusion}

Regarding clinical efficacy, both approaches for blocking the brachial plexus provided a good motor block, anesthesia, and analgesia for the operation of the forearm or hand. The supraclavicular approach proved to be relatively more successful. Our results and literature results indicate that supraclavicular and axillary access to plexus brachialis have similar clinical efficacy, although a supraclavicular block may cause more severe complications such as pneumothorax. These results suggest that an axillary approach could also be good for forearm and hand operations. However, more extensive studies will be required to compare the supraclavicular block with the axillary block using ultrasound and possible innovations.

\section{Funding/potential competing interests}

No financial support and no other potential conflict of interest relevant to this article were reported.

\section{References}

1. Fanelli G, Casati A, Garancini P, Torri G. Nerve stimulator and multiple injection technique for upper and lower limb blockade: Failure rate, patient acceptance, and neurologic complications. Study Group on Regional Anesthesia. Anesth Analg. 1999;88:847-52.

2. Bao X, Huang J, Feng H, at all. Effect of local anesthetic volume ( $20 \mathrm{~mL}$ vs $30 \mathrm{~mL}$ ropivacaine) on electromyography of the diaphragm and pulmonary function after ultrasound-guided supraclavicular brachial plexus block: a randomized controlled trial.Reg Anesth Pain Med. 2019 Jan;44(1):69-75.

3. Brown DL, Cahill DR, Bridenbaugh LD. Supraclavicular nerve block: Anatomic analysis of a method to prevent pneumothorax. Anesth Analg. 1993;76:530-4.

4. Haleem S, Siddiqui AK, Mowafi HA, Ismail SA, Ali QA. Brief reports: Nerve stimulator evoked motor response predicting a successful supraclavicular brachial plexus block. Anesth Analg. 2010;110:1745-6.

5. Perlas A, Lobo G, Lo N, Brull R, Chan VW, Karkhanis R. Ultrasound-guided supraclavicular block: outcome of 510 consecutive cases. Reg Anesth Pain Med. 2009 Mar-Apr;34(2): 171-6. doi: 10.1097/AAP.0b013e31819a3f81.

6. Franco CD, Vieira ZE. 1,001 subclavian perivascular brachial plexus blocks: success with a nerve stimulator.Reg Anesth Pain Med. 2000 Jan-Feb;25(1):41-6.

7. Baran O, Kır B, Ateş İ, Şahin A, Üztürk A. Combined supraclavicular-superficial cervical plexus block for clavicle surgery. Korean J Anesthesiol. 2018 Nov 27. doi: $10.4097 /$ kja.d.18.00296. 
8. Palaniappan S, Subbiah V, Gopalan VR, Kumar PV, Vinothan RJS. Observational study of the efficacy of supraclavicular brachial plexus block for arteriovenous fistula creation Indian J Anaesth. 2018 Aug;62(8):616-620.

9. Hamed MA, Ghaber S, Reda A. Dexmedetomidine and Fentanyl as an Adjunct to Bupivacaine $0.5 \%$ in Supraclavicular Nerve Block: A Randomized Controlled Study. Anesth Essays Res. 2018 Apr-Jun;12(2):475-479.

10. Pester JM, Varacallo M.Brachial Plexus Block Techniques. StatPearls [Internet]. Treasure Island (FL): StatPearls Publishing; 2018 Jan-2019 Jan 19.

11. Janjua MS, Pak A. Axillary Block. StatPearls [Internet]. Treasure Island (FL): StatPearls Publishing; 2018 Jan- 2019 Jan 1.
12. Brenner D, Iohom G, Mahon P, Shorten G. Efficacy of axillary versus infraclavicular brachial plexus block in preventing tourniquet pain: A randomised trial.Eur J Anaesthesiol. 2019 Jan;36(1):48-54.

13. Eguchi D, Honma K. Superficial Venous Dilatation Induced by Ultrasound Guided Axillary Nerve Block in Vascular Access Surgery.Ann Vasc Dis. 2018 Dec 25;11(4):479-483.

14. Sekar C, Mistry T, Sheela PV, Goel VK. Supra-axillary Block: A Novel Ultrasound-Guided Supplement to Brachial Plexus Block for Surgery Around Elbow.Anesth Essays Res. 2018 Apr-Jun;12(2):604-605.

15. Cornish P. Ultrasound-Guided Axillary Tunnel Block Revisited.Reg Anesth Pain Med. 2018 Apr;43(3):336-337.

Sažetak

\section{KOMPARACIJA EFEKTA BLOKADE PLEKSUS BRAHIJALISA SUPRAKLAVIKULARNIM I AKSILARNIM PRISTUPOM-NAŠA ISKUSTVA}

\section{Suljevic, O. Suljevic, M. Turan, A. Grbo i I. Šurković}

Uvod. Blok pleksus brahijalisa (BPB) je često primjenjivana metoda u regionalnoj anesteziji koji se može izvesti na nekoliko načina i lokacija. Uspješno izveden daje dobru anesteziju i analgeziju za operativne zahvate na ruci u trajanju od nekoliko sati. Može se izvoditi tehnikom izazivanja parestezije ili pomoću ultrazvuka koji je gotovo potisnuo staru konvencionalnu tehniku omogućujući vizualizaciju izvedbe blokade.

Cilj. U radu nastojimo pokazati na našem uzorku koja je od dvaju lokacija blokada povoljnija za pacijenta, odnosno koja daje veći procenat uspješnosti ili bolju senzomotornu blokadu.

Metode. Studija je retrospektivna i obuhvatila je 40 pacijenata oba spola, operisanih na Klinici za traumatologiju i Klinici za plastičnu hirurgiju Univerzitetskog Kliničkog centra u Sarajevu u periodu 30.08. 1993 do 30.08 1994. godine. Pacijenti su podjeljeni u dvije grupe. Grupa I su pacijenti koji su imali aksilarni pristup pleksus brahialisu (n-21) ASA I-II skora. Grupa II su pacijenti koji su imali supraklavikularni pristup pleksus brahialisu (n-19) ASA I-II skora. Svi pacijenti su primili 0,5 $\mathrm{ml} / \mathrm{kg}$ Bupivacaina 0,5\%. U studiji smo analizirali spol, dob, trajanje postupka blokade, komplikacije. Analgezija i motorni blok procijenjivan je 20 minuta nakon injekcije lokalnog anestetika. Kompletan blok je definiran kao analgezija u svim dermatomima (C5-Th1) 20 minuta nakon injekcije.

Rezultati. U Grupi I je bilo 20 pacijenata muškog spola i 1 pacijent ženskog spola. U Grupi II je bilo 17 pacijenata muškog spola i 2 pacijenta ženskog spola. Supraklavikularni blok omogućio je potpunu blokadu u 18 bolesnika (95,23\%), a aksilarni pristup imao je uspješnu blokadu kod 17 bolesnika (80,95\%). U obje skupine odgovarajući motorni blok bio je sličan. Vrijeme postupka je bilo brže u supraklavikularnom pristupu. Početak motornog bloka bio je sličan u obje skupine. Nije bilo značajnih komplikacija u obje skupine.

Zaključak. Sto se tiče kliničke učinkovitosti, oba pristupa za blokiranje brahijalnog pleksusa osigurala su dobar motorički blok, anesteziju i analgeziju za operaciju podlaktice ili šake. Supraklavikularni pristup se pokazao kao klinički povoljniji.

Ključne riječi: aksilarni blok, regionalna anestezija, bupivakain 